\title{
LEGAL AND HISTORICAL ASPECTS OF THE MILITIA
}

Since the President's call of the organized militia, or National Guard, of the several states into the service of the United States on June I8th last, I have frequently represented the military officers made respondents in the numerous habeas corpus proceedings brought on various grounds of alleged invalidity, usually minority, for the release of some member of the forces subjected to the call. I have found among eminent counsel and judges alike a lack of definite and discriminating comprehension, frankly acknowledged, as to what our militia is, and its relation, when called into federal service, to the Army of the United States. Indeed, more than once I was asked from the bench, "What is the militia anyway ?" The gist of what I have attempted to say in response to such questions may be of general professional interest, especially in this moment of reawakened interest in our military establishment.

\section{MILITIA AN ANGLO-SAXON INSTITUTION}

History and law concur in showing that the militia is an AngloSaxon institution. They also show beyond question that, as such, the militia from its obscure origin in Saxon times has been composed of all subjects and citizens capable of bearing arms, regardless of age or parental authority. The militia system has never recognized as affecting those parental rights over minors which are recognized in the civil relations. True it may be that from the earliest times the State has designated as liable to service those between certain ages; but this has always been a selection, made out of the entire body of the militia, of those best fitted and circumstanced to receive the training and to render the service with least disturbance to the normal economic and industrial life of the State, not for the purpose of recognizing or establishing in the parent a right to avoid a minor son's obligation to serve. Such ages of selection have always been well below twenty-one, the age of majority in the private relations, and in all periods those younger than the minimum age limit, if desirous and physically able to serve, have been permitted to do so at the option of the Government. 
As an Anglo-Saxon institution the militia in its essentials and basic principles is common alike to both England and the United States. As an institution it expresses the fundamental conception of the relations of freemen to their State. For fifteen centuries it has been a fundamental principle of Anglo-Saxon government-a fact that seems to be quite generally ignoredthat every citizen capable of bearing arms owes, in return for his liberty and protection, the duty of personal service to protect and defend his government in time of need. At its base it is an obligatory and not a volunteer system, though, chiefly perhaps because the ordinary need of the State requires the service of far less than the number available, in England until recently, and here as well, the service seems to have been regarded not as a bounden duty but as necessarily voluntary, as, of course, it is under the policy legislatively established. The Colonists brought with them here the militia system indigenous to the land of their origin. While England has turned away from that system in her present peril, as history shows she has so frequently done in like crises, the American Government on the contrary by the recent enactment of the National Defense Act has the more firmly embraced that system, including the modifying departures from basic principle, and has sought to find therein its chief reliance and protection against apprehended national dangers. Of course, England has never been troubled by that prominent constitutional feature of our own militia systemdivided control over it by the states and the nation.

\section{THE MILITIA OF ENGLAND}

Like many another Anglo-Saxon institution, the militia has passed through the historic cataclysms of England-in-the-making for fifteen centuries, and has, consequently, been modified by them but not basically changed. Until recently the system in its essentials remained as it was in its origin. The Anglo-Saxon maintained an allodial theory of land ownership, which was the measure of the military service he was obliged to render when called upon by the king in the three contingencies of trinoda necessitas. Military quotas were assigned, usually one soldier to every five hydes (a land measure); the freeholder of more than five hydes was compelled to furnish a substitute for each additional five, and, if the land was granted to tenants, the obligation to serve ran with the land. In the earliest Saxon times 
there was no age-selected class, but in the days of Alfred the obligation was primarily imposed upon those between sixteen and sixty years of age. Aspiring youths frequently commenced, however, to prepare for their military duties at an earlier age. Such age limits imposed no limitation upon the State in favor of the parent. Such was not its purpose. It was imposed for the State's own benefit. ${ }^{1}$ This Anglo-Saxon system, which recognized no parental right to which the State deferred, but which asserted its right to the military service of all regardless of other relations, reached its highest development under King Alfred. ${ }^{2}$

The particular system established by Alfred succumbed with the introduction into England, upon the Conquest, of a system of feudal military service, which itself, however, soon declined and was supplanted by the Anglo-Saxon system resurrected in a somewhat different form but without substantial change. Dependence for security at home thus again reverted to the posse comitatus armed for military service. This force was called the militia, and the system thus organized and which remained until very recent times was one, "the general scheme of which," as Blackstone said, "was to discipline a certain number of the inhabitants of every county."3 All men capable of bearing arms, regardless of age, were liable for service and were enrolled for such service, and from them volunteers or drafted men were trained and constituted what were known as "Trained Bands," the forerunner of the organized as distinguished from reserve militia. These "Trained Bands" were known and established in all American colonies. In the organization immediately after the Conquest, both law and history are obscure as to the designated age of the militia, if any, to be selected first for training and service; but in theory, and perhaps in practice, every subject capable of bearing arms, regardless of his age, was compelled to furnish himself with arms and present himself prepared for the maintenance of the king's peace." A century afterwards a fresh "assize" of arms was ordered by

\footnotetext{
${ }^{2}$ See Turner, History of the Anglo-Saxons, Vol. IV, chap. 54; Samuel, History of the British Army, p. 4; Ms. Studies of the subject by Major I. L. Hunt, Judge Advocate, U. S. A., available to me through his kindness.

${ }^{2}$ Blackstone, Commentaries (ed. Cooley) Book I, chap. I3, pp. 410, 4I3.

Ibid., p. 413 .

- (II54) 27 Henry II. 
the Statute of Wynton, which enacted that every man between the ages of fifteen and sixty, practically the ages prescribed by Alfred, should be assessed and sworn to keep armor for the protection of his lands and goods. ${ }^{5}$ The Statute of Winchester ${ }^{6}$ declared the age of the selected militia as between fifteen and sixty; so also did the Article of Inquiry of 1306.7 The Statute of Winchester was directed to be observed and kept by 5 Henry IV, chap. $3 .^{8}$ Such was the situation, as regards designated ages, at the time of the settlement of the Colonies. From I306 to I860 the system, of course, underwent many reorganizations, ${ }^{9}$ but the essential principles remained the same. It has always been a rule of English law applicable to all military service that "an enlistment is a valid contract, although entered into by a person under twenty-one years of age, who, by ordinary rules of law, except where modified by statute, cannot, as a general rule, contract any engagement." 10

\section{THE MILITIA OF THE UNITED STATES}

When the Anglo-Saxon stream divided, the militia system of that time came with us. No other American institution bears a closer resemblance to its ancient English ancestor than our militia. An examination of historic state documents of the colonies shows that all the essentials of the English system were established here. Just as the Second Amendment of our Constitution was borrowed from the Bill of Rights of I688, so did our colonial legislatures adopt the militia laws of the Motherland. The laws of the Colonies as a rule made no mention of the age of those required to render military service, though an exception is found in Massachusetts where it was provided "that every person, with certain specified exceptions, above the age of sixteen is required to serve in a military capacity." ${ }^{11}$ Clearly the purpose

\footnotetext{
'Clode, Military Forces of the Crown, Vol. I, p. 3I, citing the Statute of Winchester.

${ }^{B}$ (1285) I3 Edw. I, chap. 6; I St. Realm, p. 97.

${ }^{7}$ I St. Realm, p. 246.

${ }^{8}$ (I403) 2 St. Realm, p. 144.

- (I66I) I3 Chas. II, chap. 6; (I662) I4 Chas. II, chap. 3; (I663) I5 Chas. II, chap. 4 ; ( (I757) 30 Geo. II, chap. 25 ; (I76r) 2 Geo. III, chap. 20; (1802) 42 Geo. III, chap. 90; (1852) I5 and I6 Vict., chap. 75.

${ }^{10}$ British War Office, Manual of Military Law (1914) p. 191, citing Clode, Military Forces of the Crown, Vol. II, p. 34; Rex v. Rotherfield Greys (I823) I B \& C, 349, 350; Rex v. Hardwick (I82I) 5 B \& Ald. I76.

is (I694) General Laws and Liberties of Massachusetts.
} 
was, then, as it has been ever since, to designate those first liable, and not to create or recognize parental authority.

In such a sense the term "militia" must have been used in the several clauses of the Constitution granting a federal control over it." As was said in Lodge's FEDERALIST: "Of course, it was necessary for the legislature to form out of the whole body of militia a selected corps of moderate extent upon such principles as will really fit them for service in case of need."13 Madison, also, in the FEDERAIIST, refers to a militia of half a million citizens, evidencing the sense in which he understood the term. $^{14}$ The Constitution, in like manner, used the term "militia" in its common-law and colonial sense. ${ }^{15}$

In this country it is generally prescribed, for purposes of organization, that those who compose the militia shall be citizens between eighteen and forty-five years, but it is our view, for reasons suggested and upon the authorities discussed hereinafter, that such a designation of age limits, in and of itself, establishes no parental rights as against the state and has nothing to do with parental consent. An examination of the militia laws of the United States and the several states shows convincingly that, notwithstanding such a prescription of age-limits, if parental consent is to be required, it must be so declared by statute. ${ }^{16}$ Of course, all state law upon the subject of militia organization,

I2 See Elliot, Debates, Vol. II, pp. 312-368, et passim.

${ }^{13} \mathrm{P}$. I7I.

14 No. 46.

${ }^{15}$ See Story, Commentaries on the Constitution, Vol. II, sec. 1207; Opinion of the Justices (1866) I4 Gray (Mass.) 6r4; Ex parte Coupland (1862) 26 Tex. 387, 396; Kneedler v. Lane (1863) 45 Pa. St. 238; Cooley, Constitutional Principles, p. I00; Kent, Commentaries, p. 265.

${ }^{10}$ Looking for the present at the state constitutions and laws it will be seen that the constitutions of the following states prescribe the age limits of eighteen and forty-five years, without mention of parental consent: Florida, Georgia, Idaho, Illinois, Indiana, Iowa, Kentucky, North Dakota, Ohio, Oregon, Michigan, Missouri, Montana, South Dakota, Utah, Virginia, Washington, Wyoming.

The constitutions of the following states make no mention of age limits: Alabama, California, Connecticut, Delaware, Louisiana, New Jersey, Nebraska, Nevada, Pennsylvania, Rhode Island, Texas, Vermont, West Virginia, Wisconsin.

Statutes of the following states prescribe age limits without mention of parental consent: California, District of Columbia, Florida, Georgia, Arizona, Arkansas, Hawaii, Indiana, Iowa, Kansas, Kentucky, Maine, Minnesota, Mississippi, Missouri, Montana, Nevada, New Jersey, North 
including age limits, is in abeyance, since the National Defense Act so completely covers that field. Federal law alone governs. ${ }^{17}$

MILITIA AS DISTINGUISHED FROM FEDERAL ARMY

The militia is an English institution and was established and maintained in the Colonies and later in the several states prior to the adoption of the Constitution. It is a state as distinguished from a federal institution. ${ }^{1 s}$ Federal control over the militia is established by the Constitution wherein it provides that Congress shall have power:

"To provide for calling forth the militia to execute the laws of the Union, suppress insurrection, and repel invasions." 19

"To provide for organizing, arming, and disciplining the militia, and for governing such part of them as may be employed in the service of the United States; reserving to the States respectively the appointment of the officers, and the authority of training the militia according to the discipline prescribed by Congress."20

"The President shall be Commander-in-Chief of the Army and Navy of the United States, and of the militia of the several States, when called into the actual service of the United States." ${ }^{21}$

And in the amendments it is provided:

"A well-regulated militia being necessary to the security of a free State, the right of the people to keep and bear arms shall not be infringed." 22

"No person shall be held to answer for capital or other-

Dakota, Pennsylvania, Ohio, Oklahoma, Tennessee, Rhode Island, Utah, Vermont, Virginia, Washington, Wisconsin, Wyoming.

Statutes of the following states require parental consent for the enlistment of a minor: Connecticut, Idaho, Louisiana, Illinois, Maryland, Nebraska, North Carolina, New Hampshire, New York, South Dakota, Texas, Oregon, West Virginia.

${ }^{17}$ Houston v. Moore (I820) 5 Wheat. (U. S.) I.

${ }^{18}$ See Thorpe, Federal and State Constitutions and Colonial Charters, passim; Articles of Confederation, Art. VI; Watson, The Constitution, Vol. I, p. 690 ; see generally Houston v. Moore (1820) 5 Wheat. (U. S.) I; Luther v. Borden (I849) 7 How. (U. S.) $x$; Martin v. Mott (I827) I2 Wheat. (U. S.) I9; Elliott, Debates, Vol. II, pp. 292-309; FEDERALIST, No. 29.

${ }^{10}$ Art. I, sec. 8, cl. I5.

${ }^{20}$ Art. I, sec. 8, c1. I6.

${ }^{21}$ Art. II, sec. 2, cl. I.

${ }^{22}$ Amend., Art. II. 
wise infamous crime unless on a presentment and indictment of a grand jury, except in cases arising in the land or naval forces, or in the militia when in actual service, in time of war or public danger . . . .".23

The militia is not a federal army even when employed in federal service. The Army of the United States is exclusively a federal institution, raised, maintained, and governed directly and exclusively by the federal power under the following constitutional grants :

"That Congress shall have power . . . . to provide for the common defense . . . ."24

"Congress shall have power to raise and support armies, but no appropriation of money to that use shall be for a longer term than two years." 25

"Congress shall have power to make rules for the government and regulation of the land and naval forces."

"The President shall be Commander-in-Chief of the Army and Navy of the United States, and of the militia of the several States, when called into the actual service of the United States . . . ."27

These powers of Congress are plenary and exclusive, and the armies resulting from their exercise are the Armies of the United States. Such armies may be raised as Congress sees fit, by voluntary enlistment or compulsory draft, and they may exist as a regular establishment standing ready and available for service at all times and in all places, or temporarily for more or less definite periods and purposes. The Armies of the United States known to us in the course of our history are the Regular Army, the Volunteer Army, and, as applying to those raised compulsorily, the Drafted Army. The classification is in no sense descriptive or scientific. The Regular Army is the professional, standing establishment, continuously existing in peace and war, and, with reference to the method of obtaining the services of the citizens composing it, is as much a volunteer army as the Volunteer Army itself; the Volunteer Army is the army which Congress habitually raises for time of war to supplement the Regular Army, its existence is limited to the duration of the war, and it

${ }^{23}$ Amend., Art. V.

${ }^{24}$ Art. $\mathrm{T}$, sec. 8, cl. I.

${ }^{2}$ Art. I, sec. 8, cl. I2.

${ }^{20}$ Art. I, sec. 8, cl. I6.

${ }^{2}$ Art. II, sec. 2, cl. I. 
is composed of volunteers, hence the designation which would apply with equal appropriateness to the regular establishment; the Drafted Army, composed of all whose services are compelled instead of volunteers. ${ }^{28}$ These armies exist solely according to the will of Congress and are available to perform the national will whenever and wherever ordered, without limitation as to place or otherwise. ${ }^{28}$ From such army, or armies, the Constitution sharply differentiates the militia.

The militia is not a part of the "land forces" of the United States which Congress may govern and regulate under clause I4, section 8, Article I, of the Constitution, for special provision is made for the government of such part of it as may be employed in the service of the United States in clause $x 6$ of the same section. Neither is the militia a part of the "land forces" of the United States as the term is used in the Fifth Amendment, which excepts cases arising in such forces from the requirement of grand jury proceedings; for, in addition, the exception is expressly made applicable to the militia, when in actual service, in time of war or public danger. It is not a part of the Army of the United States of which the Constitution makes the President Commander-in-Chief; ${ }^{30}$ for the same clause expressly makes him Commander-in-Chief also of "the militia of the several States when called into the actual service of the United States." It is primarily a state and citizen soldiery rather than a national and professional soldiery. It is primarily a state institution. The United States has only a limited control over it for the limited purposes expressed by the Constitution. It cannot be used, therefore, as a national soldiery for the general military purposes. Its federal use as such is limited to home service. $^{31}$ The course of legislation and judicial decision has always marked the distinction. ${ }^{32}$

\footnotetext{
${ }^{28}$ Such armies constitute what is known as the "Army of the United States" in Art. II, sec. 2, cl. I, supra; "armies" in Art. I, sec. 8, cl. I2, supra; and "land forces" in Art. I, sec. 8, cl. 16 and Amend., Art. V, supra.

20 Tarble's Case (I87r) 13 Wall. (U. S.) 397, 408; Dines v. Hoover (1857) 20 How. (U. S.) 65; Johnson v. Sayre (1895) 158 U. S. 109, I14; In re Grimley (1890) I37 U. S. I47, I53; Ex parte Milligan (1866) 4 Wall. (U. S.) 2, I39; United States v. Sweeney (I894) I57 U. S. 28r, 284.

${ }^{30}$ Art. II, sec. 2, cl. I.

${ }^{31} 27$ Op. Att'y. Gen. 322.

A. Gt. So. R. R. v. United States (I9l4) 49 Ct. C1. 522; McClaughry v. Deming (I902) I86 U. S. 49, 5I, 58; Kneedler v. Lane (1863) $45 \mathrm{~Pa}$. St.
} 
THE NEW NATIONAL GUARD

This new force created by the National Defense Act of I9I6 must be considered in its relation to (I) the militia, and (2) the Federal Army. The term National Guard denominating this new force must not be confused with the same term hereto- . fore commonly adopted by the several states and recognized by the Dick bill.

The militia, as indicated, when defined in the most general sense and as the term is used in the Constitution, has reference to the whole body of arms-bearing citizens. Of course, Congress and, in the absence of federal legislation, the several states may further restrict the term in a legislative sense by prescribing age limits, qualifications and the like, as Congress formerly did in section $I$ of the Dick bill, ${ }^{33}$ and has more recently done in the National Defense Act as follows:

"The militia of the United States shall consist of all able-bodied male citizens of the United States and all other able-bodied males who have or shall have declared their intention to become citizens of the United States, who shall be more than eighteen years of age, except as hereinafter provided, not more than forty-five years of age. . . . .",34

The militia, thus legislatively defined, was divided by the Dick bill into (I) Organized Militia, that part of the militia arranged in the military organizations and known as the National Guard of the State, Territory or the District of Columbia, or as otherwise denominated by local law; and (2) Reserve Militia, consisting of all militia not so organized. The corresponding terminology of the National Defense Act is (I) the National Guard, and (2) the Unorganized Militia.

But "the National Guard" under the National Defense Act" is something more than was the National Guard, or organized militia, of the several states under the Dick bill. ${ }^{36}$ Under that bill National Guard, or any other local designation, was simply alter nomen for organized militia; but the National Guard under

238; McCall's Case (1863) 5 Phil. 259, Fed. Cas. 8669; Burroughs v. Peyton (1864) I6 Gratt. (Va.) 470, 483; Dunne v. People (1897) 94 I11. 120.

${ }^{33}$ (1903) 32 St. at L. 775.

${ }^{34}$ Sec. 57.

$\approx$ Sec. I.

${ }^{38}$ Sec. 57. 
the recent National Defense Act consists of the organized militia of the several states not in that single, simple status as such, but with an additional federal status required of it whereby it assumes new and onerous obligations to render military service to the Federal Government, the exact scope and extent of which are not easily determined from the language of the act; that is, the National Guard under the Hay bill has the status of the National Guard under the Dick bill, plus the new status of so-called federalization created by the new bill. The National Guard, then, is organized militia placed in a special federal status. The grave question is: Whence came the federal power to impose the new and additional status of the militia of the several states? Is the source of authority to be found in the "power" to provide for organizing, arming and disciplining the militia, ${ }^{37}$ or in the power "to raise and support armies?"38 Or is it not to be found at all? Is the National Guard still but the militia of the several states subject only to the limited constitutional use of the federal government, or is it indeed an army of the United States over which the power of Congress is unlimited? The question is fundamental, and though it received scant consideration in Congress, it may be expected to persist, if not to plague. I do no more than suggest the query with its train of constitutional difficulties, whichever way it be looked at. The lawyer disposed to consider it will encounter a host of difficulties in endeavoring to keep the authority exercised by Congress within the scope of its power over the militia as such, and a task almost or quite as strenuous in attempting to reconcile what Congress did with what it can do under its power to raise armies. The act is prickly with doubt, and it is not over-cautious to say that it will be a long time before judicial authority will have shown the way of handling it with assurance.

\section{S. T. ANsell.}

Major and Judge Advocate, U. S. A.

\footnotetext{
${ }^{37}$ Art. I, sec. 8, cl. I6.
}

${ }^{38}$ Art. I, sec. 8, cl. 12. 